\title{
The greening of Arabia: multiple
} opportunities for human occupation of the Arabian peninsula during the Late Pleistocene inferred from an ensemble of climate model simulations

\section{Article}

Accepted Version

Jennings, R. P., Singarayer, J., Stone, E. J., Krebs-Kanzow, U., Khon, V., Nisancioglu, K. H., Pfeiffer, M., Zhang, X., Parker, A., Parton, A., Groucutt, H. S., White, T. S., Drake, N. A. and Petraglia, M. D. (2015) The greening of Arabia: multiple opportunities for human occupation of the Arabian peninsula during the Late Pleistocene inferred from an ensemble of climate model simulations. Quaternary International, 382. pp. 181-199. ISSN 1040-6182 doi: https://doi.org/10.1016/j.quaint.2015.01.006 Available at https://centaur.reading.ac.uk/39673/

It is advisable to refer to the publisher's version if you intend to cite from the work. See Guidance on citing.

To link to this article DOI: http://dx.doi.org/10.1016/j.quaint.2015.01.006 
All outputs in CentAUR are protected by Intellectual Property Rights law, including copyright law. Copyright and IPR is retained by the creators or other copyright holders. Terms and conditions for use of this material are defined in the End User Agreement.

\section{www.reading.ac.uk/centaur}

\section{CentAUR}

Central Archive at the University of Reading

Reading's research outputs online 


\title{
The greening of Arabia: multiple opportunities for human occupation of the Arabian Peninsula during the Late Pleistocene inferred from an ensemble of climate model simulations
}

Richard P. Jennings ${ }^{\mathrm{a}}$, Joy Singarayerb, Emma Stonec, Uta Krebs-Kanzow ${ }^{\mathrm{d}}$, Vyacheslav Khon e,f, Kerim H Nisancioglug,h, Adrian Parkeri, Ash Parton”, Huw S. Groucutta Tom Whitea, Nick. A. Drakej, Michael D. Petraglia

aSchool of Archaeology, Research Laboratory for Archaeology and the History of Art, University of Oxford, Oxford, OX1 3QY, United Kingdom

${ }^{b}$ Centre for Past Climate Change, Department of Meteorology, University of Reading, Earley Gate, Reading, RG6 $6 B B$

cBRIDGE, School of Geographical Sciences, University of Bristol, BS8 1SS, United Kingdom

dThe Alfred Wegener Institute, Bussestraße 24, D-27570 Bremerhaven, Germany

eInstitute of Geosciences, University of Kiel, Kiel, Germany

fA.M. Obukhov Institute of Atmospheric Physics RAS, Moscow, Russia

gDepartment of Earth Science and the Bjerknes Centre, University of Bergen, Norway

hUNI Research Climate, Allégaten 55, 5007 Bergen, Norway

iDepartment of Social Sciences, Oxford Brookes University, Headington Campus, Oxford,

OX3 OBP, United Kingdom

jDepartment of Geography, King's College London, K4U.06 Strand Campus, London WC2R 2LS, United Kingdom.

\begin{abstract}
Climate models are potentially useful tools for addressing human dispersals and demographic change. The Arabian Peninsula is becoming increasingly significant in the story of human dispersals out of Africa during the Late Pleistocene. Although characterised largely by arid environments today, emerging climate records indicate that the peninsula was wetter many times in past, suggesting that the region may have been inhabited considerably more than hitherto thought. Explaining the origins and spatial distribution of increased rainfall is challenging because palaeoenvironmental research in the region is in an early developmental stage. We address environmental oscillations by assembling and analysing an ensemble of five global climate models (CCSM3, COSMOS, HadCM3, KCM, and NorESM). We focus on precipitation, as the variable is key for the development of lakes, rivers and savannas. The climate models generated here were compared with published palaeoenvironmental data such as palaeolakes, speleothems and alluvial fan records as a means of validation. All five models showed, to varying degrees, that the Arabia Peninsula
\end{abstract}


was significantly wetter than today during the Last Interglacial (130 ka and 126/125 ka timeslices), and that the main source of increased rainfall was from the North African summer monsoon rather than the Indian Ocean monsoon or from Mediterranean climate patterns. Where available, 104 ka (MIS 5c), 56 ka (early MIS 3) and 21 ka (LGM) timeslices showed rainfall was present but not as extensive as during the Last Interglacial. The results favour the hypothesis that humans potentially moved out of Africa and into Arabia on multiple occasions during pluvial phases of the Late Pleistocene.

\section{Keywords:}

Climate models, Late Pleistocene, human evolution, Arabian Peninsula, precipitation

\section{Introduction}

The timing and spatial distribution of the dispersal of Homo sapiens out of Africa is the subject of intense and continued scientific debate (e.g. Oppenheimer, 2009; Frumpkin et al., 2011; Boivin et al., 2013; Mellars et al., 2013). The consensus view is that genetic and archaeological evidence supports a major dispersal of human populations after 70,000 years ago (ka) during Marine Isotope Stage (MIS) 4 or early MIS 3 (Mellars et al., 2013). However, this has been challenged by recent archaeological discoveries and new genetic and environmental interpretations, which advocate multiple dispersals during MIS 5 (130$71 \mathrm{ka}$ ) and also later times (Boivin et al., 2013; Groucutt and Petraglia 2014; Parton et al., this issue). Central to this debate is the need to understand the environmental context of human dispersals. In regions where secure palaeoenvironmental records are incomplete or under development this is a difficult task. Here we present a different approach and assess the degree to which global climate models can inform us about past climate change and human dispersals.

Climate models are sophisticated mathematical tools that have been used in similar contexts to address key questions such as the extinction of the Neanderthals and the arrival of modern humans in Europe (Davies et al., 2003), the identification of Neanderthal refugia in southern Iberia (Jennings et al., 2011) and the modelling of human populations structures in North Africa (Scerri et al., 2014). Eriksson and colleagues (2012) have recently used one model to explore Homo sapiens dispersals out of Africa but on a larger geographic scale than we now present. Instead, we focus solely on one key region, the Arabian Peninsula. 
Those working in the Arabian Peninsula consider the region to be a critical area for understanding Homo sapiens dispersals and demography (Petraglia and Alsharekh, 2003; Marks et al. 2009; Parker et al., 2009; Armitage et al., 2011; Rose et al., 2011; Rosenberg et al., 2011, 2013; Petraglia, 2011; Groucutt and Petraglia, 2012, 2014; Crassard and Hilbert 2013; Crassard et al., 2013). Yet, the Saharo-Arabian desert belt, a hyperarid-arid expanse at $14-35^{\circ} \mathrm{N}$, has often been seen as a major biogeographical barrier for human range expansions out of Africa. However, over the last decade it has been shown that the Sahara was not always desert and that rivers, lakes and savanna grasslands developed during pluvial episodes, linked to changes in insolation (e.g. Drake et al., 2011, 2013; Larrasoaña et al., 2013). As research develops in the Arabian Peninsula, researchers are returning to ancient lakebeds previously investigated in the 1970s (e.g. Petraglia et al., 2011; Rosenberg et al., 2011, 2013; Crassard et al., 2013). Although these palaeolakes were once thought to date to MIS 3, evidence now indicates that the lakes formed during MIS 5 (Rosenberg et al., 2011; Petraglia et al., 2011). Speleothem growth, a sign of increased humidity, has also been dated to this period in caves in south and southeast Arabia (Fleitmann et al., 2004, 2007), while Late Quaternary fluvial deposits have been identified in the United Arab Emirates (UAE) (Atkinson et al., 2013).

Much of what we know about Arabia's past climate is currently undergoing extensive revision. Just as in the Sahara, the idea that the Arabian Peninsula was wetter during certain periods of the Pleistocene is rapidly developing into the null hypothesis. Recent discoveries of Middle Palaeolithic sites in stratified contexts on the shores of some of these aforementioned palaeolakes strongly suggests that modern human populations, or possibly even Neanderthals, were in the interior of the Arabia Peninsula during MIS 5 (Groucutt and Blinkhorn, 2011; Petraglia et al., 2012; Crassard et al., 2013). If savanna grassland and lakes had developed $130 \mathrm{ka}$, the idea of a coastal dispersal (cf. Mellars et al., 2013), in which the interior of Arabia was bypassed, seems highly unlikely. Instead, the presence of savanna habitats suggests that human populations would have dispersed into the region during humid periods between 130-78 ka, given their presence in Skhul and Qafzeh in the Levant (Grün et al., 2005), at Jebel Faya in SE Arabia (Armitage et al., 2011; Bretzke et al. 2013) and in East Africa (Basell, 2008) at this time. 
One of the key difficulties in testing the hypothesis that human populations inhabited the interior of Arabia during the Late Pleistocene is the lack of dated and stratified archaeological sites. For a landmass that is one quarter of the size of Europe, a small handful of dated lakebeds, speleothems and stratified sites do not provide enough evidence to link human presence to the palaeoclimatic framework. Here, we take a different approach and assess this data in the context of five climate models covering the Arabian Peninsula. We employ climate models because they are an informative way of developing insights into past climate change, especially where comprehensive palaeoclimate records are not available. Climate models take into account the major processes that shaped past climate change, such as astronomical forcing, ice sheet extent, sea-level, vegetation cover, and atmospheric greenhouse gas concentrations. The climate models provide spatial and temporal frameworks that can be tested using securely dated, independently derived sedimentological and palaeontological data (Braconnot et al., 2012; Heiri et al., 2014).

In the present article we focus on modelling precipitation, as this variable is a useful measure for determining the amount of rainfall that potentially fell across the Peninsula during the Late Pleistocene, as water, of course, was vital for the range expansion of our species (Finlayson 2014). Multiple timeslices are examined, but with a particular focus on specific periods of MIS 5e, when rainfall levels are thought to have been at their highest (Parton et al., this issue). We first review the main weather systems bringing rainfall into the Peninsula today and describe the boundary conditions used in model experiments, as understanding both is necessary before using palaeoenvironmental and archaeological evidence to assess the models and form hypotheses on human demography in the Arabian Peninsula during these periods.

\section{Present day rainfall patterns in the Arabia Peninsula}

The Arabian Peninsula supports some of the driest environments anywhere in the world. Areas of the Negev desert, north and northwest Saudi Arabia, and in the Rub Al-Khali, a vast expanse of sand desert in southern Saudi Arabia, receive mean annual rainfall levels of $<60 \mathrm{~mm}$ per annum, placing them in hyper-arid bioclimatic zones (Almazroui et al., 2012). Rainfall is more varied elsewhere in the peninsula (Figure 1), attaining an average of 75.4 $\mathrm{mm}$ in the Eastern Province of Saudi Arabia (with the highest yearly total recorded being $384 \mathrm{~mm}$ ) (Barth and Steinkhol, 2004), up to $140 \mathrm{~mm}$ per annum in the UAE (Parker, 2006), $234 \mathrm{~mm}$ per annum in Bahrain (Elagib and Abdu, 2010) and up to $400 \mathrm{~mm}$ in the $\mathrm{Al}$ Jabal 
and Al Akhdar mountains of Oman (Kwarteng et al., 2009). High levels of rainfall are also known in the Yemen highlands and in southwest Saudi Arabia, where up to $400 \mathrm{~mm}$ per annum is recorded and it can rain during every month of the year (Al-Subyani, 2005; Almazroui, 2011; Furl et al., 2014). However, decadal averages across the peninsula do not typically exceed $200 \mathrm{~mm}$ per annum outside the upland areas of SW Saudi Arabia, Yemen and Oman (Almazroui et al., 2012), meaning an arid to hyper-arid climate prevails across the vast majority of the peninsula.

\section{***Figure 1 hereabouts}

An important reason for the observed rainfall variation in Arabia is orography, where rainfall increases with elevation. For instance, the Asir Mountains (3000 m above sea level) which run parallel to the Red Sea along the western side of the Peninsula, and the Hadramaut (1500 m above sea level) in the south of Arabia receive higher rainfall than interior areas. It has been noted that there are too few weather stations to record accurately precipitation levels in such regions owing to the complex orographic variability (Abo-Monasar and Al Zahrani, 2014). Elsewhere, at Wadi Yalalam in the west of Arabia, rainfall levels are higher in the wadi's upper reaches $(220 \mathrm{~mm})$, on the western slopes of the Hijaz escarpment, than at sea level $(110 \mathrm{~mm})$ where it discharges into the Red Sea at Tihamah (Al-Subyani, 2005). Similarly, although arid and semi arid zones (receiving $<300$ $\mathrm{mm}$ ) exist on the leeward side of the $\mathrm{Al} \mathrm{Jabal} \mathrm{and} \mathrm{Al}$ Akhdar mountains in the interior of Oman, coastal regions remain humid due to monsoonal weather patterns (Kwarteng et al., 2009). In Jordan, annual rainfall levels are negligible on the southern and eastern sides of the Jordanian highlands, with only $32 \mathrm{~mm}$ recorded at Aqaba in the very south, but values exceed $500 \mathrm{~mm}$ per year on their upper western flanks, where Mediterranean conditions prevail (Freiwana and Kadioglu, 2008). As such, a strong N-S precipitation gradient exists in the Eastern Mediterranean, the Levant, and the southern Negev.

Inter-annual rainfall variability is also a strong feature of the Arabian climate (Almazroui et al., 2012). Many climate systems bring mainly low levels of precipitation to the Arabian Peninsula, each varying in timing, location, and intensity. Sometimes a single rainfall episode can provide an area with its annual rainfall total, meaning decadal averages are required to gauge patterns (Elagib and Addin Abdu, 1997; Rheman et al., 2010). The InterTropical Convergence Zone (ITCZ), a major airflow that drives monsoonal activity across 
sub-tropical latitudes of the world, is a key driver of rainfall across the Arabian Peninsula. The ITCZ moves on a continuous yearly cycle, reaching as far north as $25-30^{\circ} \mathrm{N}$ in Asia in July and as far south as $15^{\circ} \mathrm{S}$ over Africa in January (Henderson-Sellers and Robinson, 1991). Sub-tropical weather affects the south of the Arabian Peninsula in the summer months (May-September) as the ITCZ begins its move northwards. In particular, rains of the North African summer monsoon, which is a northward extension of the West African monsoon system, cross the Sahel and reach SW Arabia in July (Bosmans et al., 2014), while the Indian Ocean Monsoon reaches the southern coasts of Yemen and Oman in June (Kwarteng, 2009). The ITCZ movement is caused by seasonal land-sea thermal contrast and subsequent development of a low-pressure cell situated above the foothills of the Tibetan plateau (Fleitmann et al., 2004). Central and northern Arabia remains largely dry during these months.

During the winter (October-April), the Azores high pressure of the North Atlantic Oscillation (NAO) and the East Atlantic/West Russian (EAWR) atmospheric circulation systems drive the ITCZ southwards, which in turn generates moisture-bearing westerlies. These take the form of storms, produced as cold air masses meet warm ocean waters, which generally move along the Mediterranean basin into the Middle East and down the Arabian Gulf as far as southern Oman (Krichak et al., 2000; Barth and Steinkhol, 2004; Kwarteng, 2009; Brayshaw et al., 2010; Trigo et al., 2010; Kalimeris, 2011). The northeast winter monsoon (Van Rampelbergh et al., 2013) also brings low levels of rain to the southern coast of Arabia, particularly in January as the ITCZ moves to its most southerly position.

Other climatic systems also contribute rainfall to the Peninsula: winter air masses from the Mediterranean meet the Zagros Mountains and may develop into independent lowpressure cells that bring precipitation to north and east Arabia (Barth and Steinkhol, 2004); tropical cyclones form in the Arabian Sea in May and again in October to November and bring rainfall to the Gulf States (Kwarteng 2009); and local convection over Arabia, where a strong contrast between weather cells can occur at different times of the year and lead to rain (Barth and Steinkhol, 2004; Kwarteng et al., 2009). For example, cool northeasterly air currents from the Siberian trough can meet warm air currents from the Red Sea Trough (also known as the Sudan Trough), resulting in low-pressure, warm and 
humid air masses in November, March and April over Arabia. This may lead to low levels of rainfall (Almazroui et al., 2012; Barth and Steinkhol, 2004; Lionello 2012; Furl et al., 2014).

\section{Model configuration}

Simulations from five climate models are used here to examine the impact of changes in solar insolation, ice sheet extent, sea-level, sea surface temperature (SST), vegetation cover, greenhouse gases and other variables on the climate systems that bring rainfall into the Arabian Peninsula today. An ensemble of models is used to improve model reliability and evaluate variability between different models. All of the models are part of the Palaeoclimate Modeling Intercomparison Project (PMIP) and common boundary conditions are used to ensure the model outputs are comparable (Table 1).

\subsection{CCSM3 climate model}

This model differs from the other four models used in this study in that it is a downscaled version of the Community Climate Systems Model (CCSM3). Downscaling global climate models is undertaken to link atmospheric values generated in such models with higherresolution topographic and climate data (Jones et al., 2009). The CCSM3 model was downscaled by Hijmans et al., (2005) and made publically available on the WorldClim website. The CCSM 3 model is a fully-coupled, global atmosphere-land surface-ocean sea ice general circulation model. It comprises the atmosphere model CAM3 and the land model CLM 3 (Otto-Bleisner et al., 2006). These originally had resolutions of $1.4^{0}$ of latitude and longitude but these were downscaled to a cell resolution of 30 arc seconds (c. $1 \mathrm{~km})$. Downscaling involved a global climate surface that was interpolated from topographic (SRTM) and weather station (World Meteorological Organisation) data (Hijmans et al., 2005). This served as baseline data for the downscaling of the CCSM3 model. In this article we present the results in the form of annual precipitation for $130 \mathrm{ka}$ and for $21 \mathrm{ka}$.

\subsection{COSMOS climate model}

COSMOS is a comprehensive fully coupled Earth System Model. The atmospheric model ECHAM5 (Roeckner et al., 2003), complemented by a land surface component JSBACH (Brovkin et al., 2009) used at T31 resolution $\left(\sim 3.75^{\circ}\right)$, with 19 vertical layers. The ocean model MPI-OM (Marsland et al., 2003) including sea ice dynamics that is formulated using viscous-plastic rheology (Hibler, 1979), has a resolution of GR30 $\left(3^{\circ} \times 1.8^{\circ}\right)$ in the horizontal, with 40 uneven vertical layers. For this study we present equilibrated 
simulations of selected time slices within the Last Interglacial/Eemian (130ka, $125 \mathrm{ka}$, and 115ka) (Pfeiffer and Lohmann, 2013) and of the Last Glacial Maximum (LGM) (21ka) (Zhang et al., 2013).

As a control experiment we use a simulation equilibrated under pre-industrial conditions (Zhang et al., 2013). The boundary conditions (such as orbital parameters, green house gas concentrations, geometry of continental ice sheets and sea level) of the LGM and preindustrial simulation follow the guidelines of the PMIP. The Eemian simulations (130 ka, $125 \mathrm{ka}$, and 115ka) use the orbital configuration values of the respective time periods and a Greenland ice sheet which is diminished by reducing ice thickness by $1300 \mathrm{~m}$ at each grid point or, wherever today's ice elevation is less than $1300 \mathrm{~m}$, removing ice completely and adjusting albedo accordingly. All other boundary conditions are chosen as in the preindustrial control experiment.

\subsection{HadCM3 climate model}

The Hadley Centre climate model, HadCM3 (version 4.5), consists of a coupled atmospheric model, ocean model, and sea ice model components (Pope et al., 2000; Gordon et al., 2000). The atmosphere is a global grid-point hydrostatic primitive equation model with a resolution of $2.5^{\circ}$ in latitude by $3.75^{\circ}$ in longitude and 19 unequally spaced vertical levels. The land surface model (MOSES2.1; Essery et al. 2001) has a 'tiled' gridbox scheme with nine fractional surface types that exchange water, carbon, and energy with the atmosphere. There is a representation of freezing and melting of soil moisture and four soil depth layers. The spatial resolution of the ocean in HadCM3 is $1.25^{\circ}$ by $1.25^{\circ}$ by 20 unequally spaced layers in the ocean extending to a depth of $5200 \mathrm{~m}$. The ocean model uses the mixing scheme of Gent and McWilliams (1990) with no explicit horizontal tracer diffusion. The sea ice model uses a simple thermodynamic scheme parameterization of ice drift and leads (Cattle and Crossley, 1995).

For this study, two sets of experiments with HadCM3 were utilized. The first set of simulations cover time slices in the Eemian (130 ka, $125 \mathrm{ka}$, and $116 \mathrm{ka}$ ) and were completed as part of the PMIP3 initiative. The simulations use orbital configuration values for the relevant time slice (derived from Berger, 1978), and trace atmospheric greenhouse gases from ice core data on the EDC3 time-scale (see Table 1). Vegetation was fixed and based on pre-industrial estimates. Ice-sheets and sea level were similarly fixed at pre- 
industrial conditions. The simulations were spun up from a previous pre-industrial simulation for 550 years. The outputs described in this paper are 50 -year average climatologies following the spin-up period (Lunt et al., 2013).

The second set of simulations cover the last 120 ka with 62 snapshot simulations at roughly 2 ka intervals. In these simulations the orbital configuration is varied, as well as the atmospheric greenhouse gases, ice-sheets, and sea level (via an altered land-sea mask). The modelling methodology is described in detail elsewhere (Singarayer and Valdes, 2010; Eriksson et al., 2012). However, this study uses a slightly different version of the model to that described previously in the land surface scheme (MOSES2.1 rather than MOSES1) and in the prescribed vegetation, which in this case is fixed but taken from a previous modelled vegetation distribution from a pre-industrial ocean-atmosphere-vegetation version of HadCM3. We focus on three timeslices here: 104 ka (MIS 5a) and 56 ka (early MIS 3), which are periods of increased precipitation across the peninsula (Parton et al., this issue) and 21 ka (LGM) as a drier period.

\subsection{Kiel climate model}

The Kiel Climate Model (KCM; Park et al., 2009) is a coupled atmosphere-ocean-sea ice general circulation model. The atmosphere is represented by ECHAM5 (Roeckner et al., 2003 ) that ran in the numerical resolution T31L19 corresponding to $3.75^{\circ}$ on a great circle. ECHAM5 is coupled to the ocean-sea ice model NEMO (Madec, 2006) that has a horizontal resolution of about $1.3^{\circ}$ with enhanced meridional resolution of $0.5^{\circ}$ close to the equator. KCM shows good agreement between simulated precipitation and observations for contemporary climate, as well as with the hydrological changes that occurred during the mid-Holocene (Khon et al., 2010).

Four 1000 year-long time-slice simulations were performed using different orbital configurations [Braconnot et al., 2008]. These corresponded to four Eemian $(130,126,122$ and $115 \mathrm{ka}$ ) epochs and had been completed in a previous model experiment (Khon et al., 2010). The concentration of greenhouse gases (GHGs) was fixed to pre-industrial levels. To account for model spin-up only the last 100 years of the simulations were analysed. Here we focus on 130, 126 and 115 ka timeslices. 
The Norwegian Earth System Model (NorESM; Bentsen et al., 2013; Iversen et al., 2013), is derived from the Community Earth System Model (CESM) developed at the National Center for Atmospheric Research (NCAR). It consists of the same components for the atmosphere (CAM4), land (CLM4) and sea ice (CICE4), and uses the CESM coupler (CLP7). However, these are coupled to a version of the Miami Isopycnic Coordinate Ocean Model (MICOM) which is modified in order to improve conservation of mass and heat, and the efficiency and robustness tracer transport (Assmann et al., 2010).

The simulations used in this study are performed with the low-resolution version of NorESM (NorESM-L; Zhang et al., 2012). The atmosphere has a spatial resolution of approximately $3.75^{\circ}$ (T31) with 26 vertical levels. The ocean has a nominal grid size of $3^{\circ}$ (g37) with 30 isopycnic layers.

This study includes three Last Interglacial experiments with GHG and orbital parameters fixed to 130, 125, and 115 ka values, as described in Langebroek and Nisancioglu (2014). These were branched off a 500 year pre-industrial run and the output described in this paper are 100 year average climatologies at the end of the 1000 year integrations.

\section{Precipitation simulations}

Important aspects of the predicted precipitation levels produced by the models are briefly described. These are presented in absolute values of mm per month or, in the case of the downscaled CCSM model, mm per year. Winter (January) and summer (August) values are shown in Figures 4 to 8, with additional monthly data available in Supplementary Information 1. Beforehand, we examined pre-industrial levels of the models and evaluated how they compared with the observational data described in Section 2. This was undertaken because if pre-industrial rainfall levels are not accurate for the present day, then they may not be accurate for timeslices of the Last Interglacial. The results are shown in Figure 2. They show that HadCM3 and KCM underestimate precipitation more than NorESM and COSMOS, with NorESM the most accurate for modelling Mediterranean winter westerlies. However, it is important that none of the models overestimate pre-industrial precipitation, because any increased precipitation levels of the timeslices under study could be attributed to this observation.

\section{***Figure 2 hereabouts}




\subsection{CCSM3 climate model (Figure 3)}

130 ka: Mediterranean westerlies bring 500-1500 mm of rainfall to the Middle East, with the highest values recorded in the Lebanon-Anti-Lebanon mountain ranges. Values of 200 mm extend into Sinai and northern Saudi Arabia. Further south and in central Arabia rainfall levels exceed $600 \mathrm{~mm}$. Most other parts of the peninsula receive up to $600 \mathrm{~mm}$ per year, with a small area in south central and most of eastern Arabia receiving $<300 \mathrm{~mm}$.

\section{***Figure 3 hereabouts}

21 ka (LGM): Precipitation during the Last Glacial Maximum is restricted to three main areas: the mountains of southern Yemen, where summer rainfall levels reach $600 \mathrm{~mm}$; the Levant, where Mediterranean rainfall exceeds $1000 \mathrm{~mm}$ in the north and $600 \mathrm{~mm}$ in the southern Jordan highlands; and in central Arabia, where annual rainfall reaches $300 \mathrm{~mm}$. Elsewhere, vast tracts of the Peninsula are arid.

\subsection{COSMOS climate model (Figure 4)}

130 ka: Mediterranean winter westerlies (Nov-March) bring $200 \mathrm{~mm}$ of rainfall to northern Jordan and Syria, but hyper-arid conditions $(<80 \mathrm{~mm})$ prevail across other parts of the Arabian peninsula during the winter months. In May, weather patterns driven by the Indian monsoon bring rainfall across the southern third of Arabia, from the Arabian Gulf to the Red Sea. The rain from this monsoonal system eases in June but it is replaced by monsoonal rainfall from subtropical Africa, which spreads across the entire peninsula. This peaks in September, when it extends as far north as the Mediterranean Sea and into Syria at $34^{\circ} \mathrm{N}$. The rainfall does not entirely dissipate until December, persisting in coastal regions of the Red Sea and southern Arabia. In total for the year, $300 \mathrm{~mm}$ of precipitation falls in Syria and Jordan and up to $200 \mathrm{~mm}$ in Sinai, northern Saudi Arabia and southern Jordan, from both winter and summer rainfall. Elsewhere, $650 \mathrm{~mm}$ falls in central Arabia and as much as $1400 \mathrm{~mm}$ falls in the south of the peninsula, which is affected by both Indian and African monsoon systems.

\section{***Figure 4 hereabouts}


$125 \mathrm{ka}$ : Mediterranean winter westerlies are unchanged from $130 \mathrm{ka}$. Rainfall from Indian monsoonal activity in May covers a similar geographic range to the 130 ka simulation, but is stronger. The same can be said of the arrival of the African monsoonal rains in June, which extends north into the Sinai a month earlier than in $130 \mathrm{ka}$, and on into the Mediterranean Sea and as far north as Syria. In total, 400 of precipitation falls throughout the year in Syria and northern Jordan, $250 \mathrm{~mm}$ in southern Jordan, Sinai and northern Saudi Arabia, $760 \mathrm{~mm}$ in central Arabia, and as much as $1800 \mathrm{~mm}$ in the south of Arabia.

$115 \mathrm{ka}$ : The Mediterranean winter westerlies lose intensity and do not extend into the Middle East beyond February. A period of rainfall in southwestern Arabia occurs in June and remains until September, occasionally integrating with Indian and African monsoonal activity, which in marked contrast to $130 \mathrm{ka}$ and $126 \mathrm{ka}$ simulations that never significantly penetrate into the peninsula. Total annual rainfall in the Syria and northern Jordan does not exceed $100 \mathrm{~mm}$, while levels in the south do not exceed $500 \mathrm{~mm}$.

21 ka (LGM): The coldest time of the last glacial brings extreme aridity to the Arabian Peninsula. From Nov-Feb, Mediterranean westerlies bring $200 \mathrm{~mm}$ of rainfall no further south than $28^{\circ} \mathrm{N}$. There is almost no rainfall from March-June in the peninsula, and from July-August it is restricted to SW Arabia and there it does not exceed $200 \mathrm{~mm}$.

\subsection{HadCM3 climate model (Figures 5 and 6)}

130 ka: Two weather systems dominate rainfall: the Mediterranean westerlies, which brings rain into southern Jordan and the Arabian Gulf, and the summer monsoon, which extends in August up the Red Sea and across SW Arabia. Total annual rainfall in both the Mediterranean and SW Arabia is $100-650 \mathrm{~mm}$, but in intervening areas rainfall is low $(<80$ $\mathrm{mm}$ ). The majority of the rainfall in central Arabia arrives in April-May when a weather front extends from the Arabian Gulf and meets weather patterns coming up from subtropical Africa ahead of the arrival of the full monsoon in SW Arabia. The southern rainfall belt reaches $22^{\circ} \mathrm{N}$ in August.

125 ka: Mediterranean westerlies bring similar rainfall amounts as seen in the $130 \mathrm{ka}$ simulation. Levels are more intense in SW Arabia than at $130 \mathrm{ka}$ as they exceed $500 \mathrm{~mm}$ 
per year and reach $23^{\circ} \mathrm{N}$, but the arid zone over central Arabia still persists, with rainfall not above $100 \mathrm{~mm}$ per annum in these areas.

***Figure 5 hereabouts

***Figure 6 hereabouts

116 ka: Mediterranean westerlies once again remain constant compared with early simulations, but rainfall contracts and reduces to $400 \mathrm{~mm}$ in SW Arabia. Large areas of central Arabia are hyper-arid as they receive $<20 \mathrm{~mm}$ of annual rainfall.

$104 \mathrm{ka}$ (MIS 5c) and $56 \mathrm{ka}$ (mid MIS 3): Rainfall is very similar to the $130 \mathrm{ka}$ and $125 \mathrm{ka}$ simulations, but patterns are marginally less intense and extensive.

21 ka (LGM): Mediterranean weather patterns are consistent with the 116 ka simulation. It is in the south of the peninsula where rainfall is most different from the 116 ka timeslice but $20 \mathrm{~mm}$ annual rainfall still persists in SW Arabia. Intervening areas are hyper-arid $(<40$ $\mathrm{mm})$.

\subsection{Kiel Climate Model (Figure 7)}

130 ka: From Nov-March, Mediterranean westerlies bring rainfall levels of at least $120 \mathrm{~mm}$ per year to the windward side of the Lebanon and the anti Lebanon mountain ranges in Syria, only $60 \mathrm{~mm}$ in southern Jordan, and even less in Saudi Arabia and the Sinai peninsula. By April and May, the westerlies disappear as the ITCZ moves northwards, bringing slight rainfall to the south of Arabia. Subtropical precipitation from Africa and minor contributions from the Indian monsoon falls from June to September up to $27^{\circ} \mathrm{N}$, in line with the head of the Arabian Gulf and the Sinai. The rainfall all but disappears from the peninsula in October. The highest rainfall levels reach $460 \mathrm{~mm}$ per annum in the south of the peninsula.

126 ka: Mediterranean westerlies are marginally weaker from Nov-March during the last interglacial peak than at $130 \mathrm{ka}$. They, however, increase in intensity in the south as the ITCZ moves northwards and the African monsoon system brings intensive rainfall of up to 
$600 \mathrm{~mm}$, with rainfall lasting from June right through to September once again, followed by an almost arid October. The rain from the south reaches $29^{\circ} \mathrm{N}$.

***Figure 7 hereabouts

115 ka: Mediterranean winter westerlies weaken and extend no further south than Jordan at their peak in January. By April they disappear from the Middle East while the southerly rainfall that characterised the $130 \mathrm{ka}$ and $126 \mathrm{ka}$ timeslices during this month does not appear until May. Light rainfall linked to the African monsoon also arrives during this month, three months later than $126 \mathrm{ka}$. It only passes over southern Arabia up to $19^{\circ} \mathrm{N}$ and rainfall remains at low intensity until November, giving a peak of only $120 \mathrm{~mm}$ of rainfall per year.

\subsection{NorESM climate model (Figure 8)}

$130 \mathrm{ka}$ : The Mediterranean winter westerlies arrive in the Middle East in October and extend into the Sinai and northern Saudi Arabia in November. They retreat from these areas in March but sweep around from the Arabian Gulf into Central Arabia to bring light rainfall into this region. In April, this rainfall links to rainfall entering the Arabian Peninsula from the SW, a precursor to the arrival of the African monsoon in June. In July, rain from the African and Indian monsoons create a band of rainfall that covers the southern half of Arabia. These reach their northward peak in August, bringing rain to around $28^{\circ} \mathrm{N}$. They weaken the following month with African monsoonal activity recorded in SW Arabia at the same time the Mediterranean westerlies bring rainfall to the northern Levant. Total annual rainfall in Sinai and northern Saudi Arabia is 160 mm, central Arabia 200 mm, and in southern Arabia it is $450 \mathrm{~mm}$.

$125 \mathrm{ka}$ : The Mediterranean winter westerlies do not extend south over the entire Sinai as they do in 130 ka simulation, and the rainfall sweeping into central Arabia in March is also weaker. This connects with rainfall from NE Africa in April-May to create a SW-NE band of light rainfall across the peninsula. African and Indian monsoonal activity is broadly the same as in the 130 ka simulation, though it is stronger and persists further north in September. 


\section{***Figure 8 hereabouts}

$115 \mathrm{ka}$ : There is a strengthening of the Mediterranean westerlies in the Arabian Gulf and central Arabia compared with the $130 \mathrm{ka}$ and $125 \mathrm{ka}$ simulations and the simulation provides a particularly pronounced arrival of the westerlies in November, which bring light rainfall as far south as NE Africa. A weakened African monsoon system is the reason for an absence of interconnectivity between Mediterranean and African weather patterns in April and May. African and Indian monsoonal rainfall arrives in July, is light, extends no further than SW Arabia and Oman, and is gone by September.

\subsection{Summary}

All models simulate the main aspects of the weather systems of Arabia, however some are much wetter than others. For the 130 ka timeslice, models exhibiting extensive rainfall patterns are CCSM3, which shows rainfall originating in Africa as far north as northern Arabia in the summer months, and COSMOS, which shows rainfall from Africa reaching the Mediterranean Sea. The African monsoonal rains reach central Arabia in the KCM and NorESM models, and in southern Arabia for HadCM3. Mediterranean winter westerlies are most pronounced in the NorESM and HadCM3 models, with rainfall shown reaching the Arabian Gulf. In terms of intensity, Rainfall levels are highest in SW Arabia, where they range from $1400 \mathrm{~mm}$ per year for the COSMOS model to $450 \mathrm{~mm}$ per year for HadCM3. These patterns strengthen slightly for the four models used to convey precipitation at 126 / $125 \mathrm{ka}$. There is then a noticeable decline in summer precipitation in the $115 \mathrm{ka}$ timeslices of the four models, with levels below present day values in all cases. The same reductions are seen in rainfall of the Mediterranean winter westerlies, with the one exception being NorESM, which shows a minor increase in rainfall a 115 ka compared with $125 \mathrm{ka}$. Timeslices of the HadCM3 model for $104 \mathrm{ka}$ and $56 \mathrm{ka}$ show patterns similar to their $125 \mathrm{ka}$ timeslice where rainfall is shown in the southern parts of Arabia. Three timeslices for 21 ka have the lowest levels of rainfall of any of the periods investigated. We can now evaluate the veracity of these models by comparing them to palaeoclimate data.

\section{Palaeoclimate records and comparison of observations and simulations}

In order to investigate the utility of these models we now compare the simulations with palaeoenvironmental data for the peninsula (Figure 9). Working from south to north, there is firstly good agreement between the simulations of the Last Interglacial and 
palaeoclimatic records in south Arabia. Speleothem growth at Mukalla Cave in southern Yemen at $14^{\circ} \mathrm{N}$ has been dated using Uranium-series (230Th) to $130-123 \mathrm{ka}$, which indicates that more than $300 \mathrm{~mm}$ of rainfall occurred in a location that today receives 150 mm per year (Fleitmann et al., 2007). KCM simulations show that $320 \mathrm{~mm}$ of rainfall fell at Mukalla at $130 \mathrm{ka}$ and $380 \mathrm{~mm}$ at $126 \mathrm{ka}$, while the COSMOS model records $750 \mathrm{~mm}$ at 130 $\mathrm{ka}$ and $865 \mathrm{~mm}$ at $125 \mathrm{ka}$. The CCSM3 models records $400 \mathrm{~mm}$ of rainfall at $130 \mathrm{ka}$ for its only timeslice of the Last Interglacial. Values of the NorESM and HadCM3 simulations are higher than present but fall just short of the speleothem growth estimates, with yearly amounts of $280 \mathrm{~mm}$ and $200 \mathrm{~mm}$ respectively for the $126 \mathrm{ka}$ and $125 \mathrm{ka}$ timeslices.

Two large palaeolakes at Mundafan and Khujaymah allow for the models to be evaluated in the interior of Saudi Arabia, at $18.3^{\circ} \mathrm{N}$. Both are located in the Rub' Al Khali desert where rainfall today is extremely low. While no deposits dating to 130 ka were recorded at Mundafan, freshwater lake marls at Khujaymah are bracketed by Optically Stimulated Luminescence (OSL) ages of $120 \pm 10 \mathrm{ka}$ and $136 \pm 14 \mathrm{ka}$, indicating interglacial lake formation (Rosenberg et al., 2011). It is not clear how much rainfall is required to generate lakes as this depends partly on the topography of the lake basin, its surrounding terrain, and the size of catchments. Modelled annual precipitation values for the area for $125 \mathrm{ka}$ are $200 \mathrm{~mm}$ (HadCM3), $280 \mathrm{~mm}$ (NorESM), $300 \mathrm{~mm}$ (CCSM3), $580 \mathrm{~mm}$ (KCM), and $740 \mathrm{~mm}$ (COSMOS). While there is considerable variation in these yearly totals, the lowest values are more than three times present day rainfall levels in the Rub' Al Khali and reflect a significant increase in last interglacial precipitation in this part of the Arabian peninsula, compared to the present day.

Further to the southeast in Oman, speleothem formation at Hoti Cave at $23^{\circ} \mathrm{N}$ and the presence of Saiwan palaeolake at $20^{\circ} \mathrm{N}$ dated to $132-104 \mathrm{ka}$ indicate that SE Arabia also experienced increased rainfall in the Last Interglacial (Rosenberg et al., 2011). Additionally, fluvial and alluvial fan deposits near Al Ain in the UAE at $24^{\circ} \mathrm{N}$ (Parton et al., 2014, in submission) represent the activation of drainage systems in southeast Arabia, and also date to the Last Interglacial (c. $130 \mathrm{ka}$ ). Fluvial systems in the UAE also show that rivers were flowing at least $400 \mathrm{~km}$ and into the Persian Gulf during MIS 5 based on OSL ages from the Hili formation gravels in Abu Dhabi (Parton, 2013). KCM, NorESM and HadCM3 have annual values of 120-140 mm, which are too low for speleothem formation at Hoti Cave, and likely for the formation of a large freshwater lake in the Saiwan basin, or within the 
southern Rub al Khali. COSMOS predicts $420 \mathrm{~mm}$ for Hoti Cave and $300 \mathrm{~mm}$ at the Saiwan basin at $125 \mathrm{ka}$, which agrees best with the available data. Further, the models show that the wetness was not necessarily exclusively from an African monsoon source. Rather, the models suggest that rainfall in these regions is derived from both African and Indian monsoon activity.

\section{***Figure 9 hereabouts}

Unfortunately, there are no dated palaeoenvironmental sites in central Arabia with which to validate the models. Many of the models, however, show adequate rainfall in this area, which is reasonable, given the potential extent of increased humidity indicated by the wider palaeoclimatic record. Future validation may be provided by dates from speleothem formations at Surprise Cave at $26^{\circ} \mathrm{N}$, which are located in central Saudi Arabia (Fleitmann et al., 2004).

Moving further northwards, the next palaeoenvironmental datasets encountered to test the model simulations are in the Nefud desert in nort-central Saudi Arabia at $27^{\circ} \mathrm{N}$. Palaeolakes have recently been dated to 130-115 ka in the western Nefud near Tayma (Rosenberg et al., 2013), and at Jubbah Palaeolake near Ha'il (Petraglia et al., 2011), but only one set of deposits has been dated with reasonable certainty. These are at an interdunal locality within the western Nefud (Rosenberg et al., 2013). Sand above and below a $0.50 \mathrm{~m}$ thick layer of lacustrine diatomites and plant remains was dated using OSL to $128 \pm 9$ ka and 125

\pm 10 ka respectively. The KCM, HadCM3 and NorESM models suggest annual rainfall at 126 ka or 125 ka here was less than $100 \mathrm{~mm}$, likely too low to sustain lakes unless seasonally recharged by groundwater. However, COSMOS and CCSM3 models are more in agreement with lake formation at this time, with annual rainfall values of $280 \mathrm{~mm}$ and $300 \mathrm{~mm}$ respectively.

When moving into the north of the peninsula, it is important to consider what impact advancing winter Mediterranean westerlies had upon rainfall totals in northern Arabia. However, rainfall from this direction appears to be low during the entire Last Interglacial for all of the models. The westerlies indicate rainfall of at least $120 \mathrm{~mm}$ per annum in north Jordan and Syria, falling on the western Lebanon and the Anti-Lebanon mountain ranges. Thereafter, rainfall levels decline abruptly to the south. At $130 \mathrm{ka}$, the COSMOS and 
HadCM3 simulations show that winter westerlies contribute $<80 \mathrm{~mm}$ per year of rainfall in the Arabian Peninsula, while the KCM model indicates $<60 \mathrm{~mm}$. The NorESM model, in contrast, shows the greatest southerly excursion of the Mediterranean weather patterns, reaching Sinai and northern Saudi Arabia at $29^{\circ} \mathrm{N}$ but still contributing only $100 \mathrm{~mm}$ per annum. Rainfall from the westerlies less or is unchanged in the $126 \mathrm{ka}$ and $125 \mathrm{ka}$ simulations. By $115 \mathrm{ka}$, rainfall is restricted to north Jordan in the COSMOS, KCM and HADCM3 models, but in the NorESM model it extends as far south as northeast Africa, albeit at low levels.

Muduwwara palaeolake is an important locality to validate the models in the north of the peninsula. The site comprises a series of large basins located in southern Jordan on the border with Saudi Arabia at $29.3^{\circ} \mathrm{N}$ and provides evidence for lake formation. A range of Uranium/Thorium dates on Cerastoderma shells were generated, with those at Site 4 of relevance to the climate models under evaluation, providing a date for lake formation in the depression of $125 \pm 5$ ka (Petit Maire et al., 2010). However, only three of the models, NorESM, COSMOS and CCSM3, produce levels of rainfall in excess of $100 \mathrm{~mm}$ for the area, the latter two with rainfall contributions from the African monsoon. It would seem unlikely that such little rainfall would have been sufficient to form a lake that investigators suggest was up to $2000 \mathrm{~km}^{2}$ and $>40 \mathrm{~m}$ deep. Alternatively, the surrounding hydrological catchment, which incorporates mountains in Jordan and Saudi Arabia, may have provided sufficient stream discharge into the Mudawwarra basin to enable lake formation (Petit Maire et al., 2010). Alternatively, of course, the models may need refining in this area.

As the assessment of the climate models moves north to Syria, north Jordan and Israel, a number of cave speleothems provide palaeoclimatic data for 130-115 ka and later pluvial periods. Records from the central and northern Negev reveal an intensification of rainfall during the Last Interglacial between c. 137 and 123 ka (Bar-Matthews et al., 2003; Vaks et al., 2003; 2006; 2007; 2010), with precipitation in the central Negev in excess of $300 \mathrm{~mm}$ (Vaks et al., 2010). Forests recorded in the Lebanon Mountains also suggest high rainfall levels in this region during this time (Jeffers and Willis, 2014). Within the southern Negev, however, rainfall was limited, due to a strong N-S precipitation gradient, suggesting that the convection of moisture from the Mediterranean did not pass southwards beyond this region. There is some discrepancy between records from the Negev and Levant regions for 130-115 ka. While increased rainfall is recorded at Soreq and Peqiin caves, generally drier 
conditions are reported from the Dead Sea region (Torfstein et al., 2009; Sorin et al., 2010; Waldmann et al., 2010). These discrepancies have led to a dichotomy of opinion regarding the response of the Mediterranean climate during glacial/interglacial cycles. It has been suggested that the apparently conflicting climate signals from these regions is due to advancements of synoptic troughs fromn the Red Sea, that are superimposed on the Mediterranean climate signal (Waldmann et al., 2010).

Up to this point the focus of the evaluation has centred on 130-115 ka because this is the period for which all of the climate models have published outputs. However, it is possible to briefly investigate later periods with the HadCM3 model because timeslices for many intervals of the last interglacial/glacial cycle have been generated with this model. The HadCM3 simulation for 104 ka correlates well with palaeoenvironmental evidence from Mundafan palaeolake, where sand deposits immediately above and below lake marls were dated using OSL to $103 \pm 8$ ka and $101 \pm 6$ ka respectively (Rosenberg et al., 2011). The 104 ka simulation indicated that Mundafan received $300 \mathrm{~mm}$ of annual rainfall while its catchment area to the west and southwest received 400-500 mm per year. In nearby Khujaymah palaeolake, sand beneath lacustine deposits has been dated using OSL to $88 \pm 6$ ka, suggesting another possible MIS 5a lake (Rosenberg et al., 2011). Elsewhere where palaeoenvironmental evidence exists for $104 \mathrm{ka}$ and for $56 \mathrm{ka}$, such as at Hoti Cave (Fleitmann et al., 2003; 2011), the western Hajar alluvial fan/fluvial records, UAE (Farrant et al., 2012; Parton et al., 2013; 2014), and the palaeolakes of Jubbah and the western Nafud (Petraglia et al., 2011; Rosenberg et al., 2013), HadCM3 timeslices do not suggest rainfall. There are no known terrestrial records to test the 21 ka models.

\section{Discussion}

A number of points emerge from the examination of the climate models. They noticeably demonstrate a substantial increase in rainfall over large areas of the peninsula during the Last Interglacial, indicating that the region was likely to have been significantly more vegetated than today. This conforms well to palaeomonsoon data, which shows that monsoon maxima correspond with peaks in summer insolation and an associated northward shift of the ITCZ (Parton et al., this issue). The North African summer monsoon was the major source of increased rainfall across Arabia rather than the Indian monsoon or the Mediterranean winter westerlies, which contributed minimal increases in rainfall over 
the peninsula. The incursion of intensified monsoonal rainfall is generally well supported by speleothem growth and the existence of palaeolakes across the peninsula.

While all of the climate models demonstrate an increase in rainfall in Arabia from subtropical Africa during the Last Interglacial, they vary signficantly in terms of precipitation range and quantity. The two models that display the greatest spatial extent of rainfall are the COSMOS and CCSM3 simulations for $125 \mathrm{ka}$ and $130 \mathrm{ka}$ respectively. These show that sub-tropical African systems driven by the ICTZ brought rainfall as far north as the Mediterranean Sea at $34^{\circ} \mathrm{N}$. The next most expansive simulations are the KCM $125 \mathrm{ka}$ simulation, which shows rainfall from Africa in Sinai at $29^{\circ} \mathrm{N}$, and the NorESM $125 \mathrm{ka}$ simulation, which indicates that rainfall was in NW Saudi Arabia at $28^{\circ} \mathrm{N}$. The model with the smallest rainfall imprint from Africa is HadCM3, which shows that precipitation extended only mid-way up the peninsula to $23^{\circ} \mathrm{N}$. Comparison with palaeoclimate records suggests that the wetter models are likely the most realistic.

The reasons the models vary are due to differences in model physics and coupling, sub-grid scale parameterizations (especially relating to atmospheric convective activity), spatial resolution, and boundary conditions. For example, Braconnot et al. (2007) assessed the response of PMIP2 models to mid-Holocene (6 ka BP) orbital configuration. All models involved displayed northward movement of the boreal summer ITCZ, especially over Africa. The models that included dynamic vegetation feedbacks with the atmosphere-ocean system displayed larger wetting in the Sahel region than those with fixed vegetation. However, it is important to note that all PMIP2 and PMIP3 models underestimate the northward movement of the ITCZ and coincident increase in rainfall compared to palaeoclimatic reconstructions (Braconnot et al., 2007; Perez-Sanz et al., 2014). In another study comparing two atmospheric models coupled to the same land biogeography model it was found that differences in the atmospheric models themselves resulted in significantly different tropical circulation responses to mid-Holocene orbital configuration (de NobletDucoudre et al., 2000). Differences in boundary conditions are also important, and in some cases dominate other factors. For example, DiNezio and Tierney (2013) demonstrated the importance of prescribing lower sea level at the LGM by examining the performance of a range of LGM climate model simulations in a model-data comparison for the Indo-Pacific region. Exposure of the Sunda Shelf was critically important to matching reconstructed changes to the glacial Indian Ocean hydrologic pattern, due to its impact on the Walker 
circulation. The models that best simulated these patterns included lower sea level and exposure of the shelf in the Indo-Pacific.

The models detect climate changes within the Last Interglacial. Precipitation was greatest at $125 \mathrm{ka}$ rather than at $130 \mathrm{ka}$. Conversely, last interglacial precipitation levels were at their lowest as the last interglacial ended at $115 \mathrm{ka}$. This pattern conforms with global and regional palaeoclimatic data and was repeated in all of the models. In term of seasonality, four climate models show that as sub-tropical African monsoon rainfall advanced in the summer months during $130 \mathrm{ka}$ and the 126/125 ka, Mediterranean winter westerlies remained stable or also increased. As the summer subtropical rains contracted in the 115 ka simulations, so did the winter westerlies. The only exception was the NorESM model for $115 \mathrm{ka}$, which showed an increase in winter rainfall when summer rainfalls were in decline. As such, the models generally provide some, albeit inconclusive, support to the suggestion that Mediterranean and monsoon systems intensify in concert during mid-high latitude interglacials.

There were also subtle shifts in timing of weather patterns, although the peak month of rainfall was the summer month of August in all cases. The minor shifts concerned the Mediterranean winter westerlies, which during four $115 \mathrm{ka}$ simulations end in the Middle East between Jan-March rather than March-April in the 126/125 ka peaks. This shorter winter rainfall season must have had an impact on vegetation patterns in this area. In the Lebanon Mountains, forests gave way to grassland and steppe environments at the end of the Last Interglacial (Jeffers and Willis, 2014). Indeed, a shortened rainy season may have also impacted upon drip and speleothem growth rates which in turn, may have led to the apparent dichotomy of records from the Negev and Levant regions.

While the focus of the climate simulations is on the Last Interglacial, there is good evidence that MIS 5c, MIS 5a, and early MIS 3 (c.56 ka) were also pluvial phases that brought rainfall to the Arabian Peninsula. The HadCM3 model is the only one currently available to evaluate these phases, and even though it is the most conservative of the models under evaluation in terms of the amount of rainfall it showed for Arabia during MIS 5e, it indicates an increase in rainfall for each of these timeslices, and that rainfall derived from sub-tropical Africa, albeit at a marginally reduced intensity than seen for the Last Interglacial. 
In periods of reduced precipitation, such as $115 \mathrm{ka}, 21 \mathrm{ka}$, and today, there is a substantial fall in precipitation across the peninsula in all models, but with levels still high enough in the south and southeast to ensure that grassland and subtropical refugial environments have persisted in these areas throughout the last 130,000 years.

\section{Implications for human demography}

In Arabia, the Middle Palaeolithic is known from several hundred sites and has been the topic of several publications (e.g. Petraglia and Alsharekh, 2003; Crassard, 2009; Armitage et al., 2011; Rose et al., 2011; Delagnes et al., 2012; Groucutt and Petraglia, 2012; Petraglia et al., 2012; Usik et al., 2013; Scerri et al., in press; Groucutt et al., this issue; Scerri et al., this issue). The vast majority of sites occur from surface contexts, and so lack chronometric age estimates. Nevertheless, these surface sites provide extremely important information on technological variability in Arabia as well as insights into hominin landscape use.

Figure 10 shows the distribution of published Middle Palaeolithic sites (updated from Groucutt and Petraglia, 2012) on the CCSM3 model timeslice for $130 \mathrm{ka}$, which conveys high rainfall levels and is used as an analogy for a pluvial phase. The black dots refer either to individual sites or to clusters of sites. In Dhofar, Oman, for example, hundreds of Middle Palaeolithic sites have recently been discovered due to extensive surveys (Rose et al., 2011; Usik et al., 2013) and these are represented by a single black dot. There may be surveying biases in the dataset, for instance the distribution map shows a line of sites extending along the survey route to the northwest of Riyadh. Despite this, it is likely that at a peninsula wide level the distribution of sites does reflect, or at least mirror, something of the real distribution of sites.

\section{***Figure 10 hereabouts}

Little has been published on the technological and behavioural aspects of most of the Middle Palaeolithic sites of Arabia. Nevertheless, there are some key anchor points across Arabia. Jebel Faya (Armitage et al., 2012) in the eastern UAE presents a series of Palaeolithic assemblages. This site is situated beside a patch of land in which the climate model suggests was more humid than surrounding regions. Along with the topographic variability of the area (i.e. the Gulf to the Hajar of Oman), such environmental factors may 
explain the repeated occupation of the site. In the Huqf area of Oman the extensive Palaeolithic record presents itself with a generally idiosyncratic character (Jagher, 2009). For example, the abundant Nubian cores found a few hundred kilometres to the southwest are apparently entirely absent from this area. The climate models show that the east of Arabia was arid even during periods such as MIS 5, which may suggest a considerable (i.e. Middle Pleistocene) antiquity for many of these sites. Nubian Levallois technology was first recognised in Yemen (Inizan and Ortlieb, 1987; Crassard, 2009) and subsequently found in far great abundance in the neighbouring Dhofar region of Oman (Rose et al., 2011; Usik et al., 2013). Most recently, this technology has been identified near Al Kharj in central Arabia (Crassard and Hilbert, 2013). The climate model shows that these sites are all in the 300$600 \mathrm{~mm}$ per year rainfall zone.

The CCSM3 climate model suggests that sites demonstrating an alternative form of technology focused on centripetal Levallois technology (Groucutt et al., this issue) saw much increased rainfall. These included Mundafan in southwest Saudi Arabia (Crassard et al., 2013), sites in the UAE such as Jebel Barakah (Wahida et al., 2009), and sites in northern Saudi Arabia such as Jebel Qattar 1 and Jebel Umm Sanman 1 (Petraglia et al., 2012). At Jubbah in the Nefud desert, sites such as JKF-1 have been interpreted as demonstrating similarities to sampled NE African sites (Scerri et al., in press), but others are reminiscent of the Levantine late Middle Palaeolithic (Crassard and Hilbert, 2013), suggesting possible MIS 5 or 3 connections to the north. In this sense the emerging picture suggests a more complex and varied Middle Palaeolithic record in northern than in SE Arabia.

Finally, the sites of Wadi Surdud in Yemen, particularly SD-1, present a series of important and well-dated occupations (Delagnes et al., 2012). A suite of OSL dates firmly associates the major human occupation with MIS 3 (c. $55 \mathrm{ka}$ ). This correlates with the 56 ka pluvial phase of the HadCM3 model shown in Figure 6. Palaeoenvironmental reconstruction and faunal analysis suggest at least semi-arid condition during the occupation of the site. The technological characteristics of SD-1 are unique, with reduction of non-Levallois character focussing on simple hard hammer reduction of single platform cores to produce blades and elongated points (Delagnes et al., 2012). While the ancestry of the occupants remains unclear, the evidence suggests occupation of a refugial area that climate models demonstrate was always one of the most humid parts of Arabia. Finally, at Jebel Faya, 
Assemblages B and possibly A represent MIS 3 occupations and again suggest a contraction to a refugial zone, in this case the environs of the Gulf which was exposed as a large river valley for most of the Pleistocene.

\section{***Figure 11 hereabouts}

Many questions remain, including the character of Middle Palaeolithic assemblages in the far north of Arabia, which our models suggest generally remains arid. Likewise, the Middle Palaeolithic of highland SW Arabia remains little understood before MIS 3, although scattered lithics are reported from MIS 5 (Delagnes et al., 2012). However, overall, there is a strong correlation between Middle Palaeolithic sites distributions and areas with dry to sub-humid precipitation (Figure 11). This demonstrates the importance of rainfall in the ranging of hominin populations across the Arabia Peninsula during the Late Pleistocene.

\section{Conclusions}

The ensemble of climate models presented here show that the Arabian Peninsula was substantially wetter than today, particularly in the Last Interglacial. Several other periods saw the peninsula receive increased rainfall, including in MIS 5c, MIS 5a, and during the major pluvial peak in MIS 3, at $56 \mathrm{ka}$. The comparison of emerging empirical data with simulations of the Last Interglacial, the wettest period of the last 130,000 years, demonstrate that climate models provide a useful framework to interpret what is a currently a limited set of terrestrial palaeoenvironmental data. The models help to understand the patterns and processes behind why Arabia was wetter in the past. Increased rainfall helps to explain why so many Middle Palaeolithic sites exist in areas that are hyperarid-arid today. A wetter climate in the past would have, of course, sustained hunter-gatherer populations across much of the peninsula.

Though there is a considerable way to go before the models can be said to represent the past climate of Arabia, our research represents a first step towards characterization of potential environments. The next phase of research is to develop multiple regional climate models for the peninsula, which will factor in variables such as land surface topography and more accurate boundary conditions. Ideally, such models will incorporate vegetation evidence and lake deposit data as these are potential feedback mechanisms that increase precipitation levels further. Future models will also hopefully have timeslices with 
thousand-year periodicity in order to pick up changes through time. Other variables may also be factored in, such as wind speed, evapotranspiration and air temperature. Regional models will be useful to detect the smaller-scale weather patterns that bring rainfall into the peninsula, something that the current simulations do not detect. All of this will allow us to develop testable biogeographic models of the Arabian Peninsula.

\section{Acknowledgements}

We acknowledge funding support from the European Research council (ERC) to M.D. Petraglia (Advanced Grant 295719 'PALAEODESERTS: Climate Change and Hominin Evolution in the Arabian Desert: Life and Death at the Cross-roads of the Old World'). We appreciate the support of the Saudi Commission for Tourism and Antiquities. We thank the members of our team for their contributions, particularly Dr. Abdullah Alsharekh (King Saud University) and Abdulaziz al Omari (SCTA).

\section{Figures}

Figure 1: Present day rainfall levels of the Arabian Peninsula derived from WorldClim data. Arid to hyperarid levels prevail across the Peninsula, with exceptions in Yemen, Oman, and parts of Jordan, where levels exceed $300 \mathrm{~mm}$ per annum.

Figure 2: Pre-industrial precipitation levels of four climate models used in this study. The levels represent (NorESM and COSMOS) or under-represent (HadCM3 and KCM) the main elements of Arabian precipitation but do not detect local climate systems. That the models do not over-represent present day values means increased rainfall levels seen in climate models of past conditions is not a result of present day biases.

Figure 3: The CCSM3 climate model timeslice of 130 ka shows that Arabia was wetter at this time than the present day. The dominant green colour equates to rainfall levels of 300$600 \mathrm{~mm}$ per year. Orange in Northern Arabia represents the contracted Saharo-Arabian desert belt where rainfall levels were $<100 \mathrm{~mm}$ per year.

Figure 4: Winter (January) and summer (August) rainfall levels of the COSMOS climate model. These show that the Arabian Peninsula was much wetter at $130 \mathrm{ka}$ and $125 \mathrm{ka}$ than $115 \mathrm{ka}$ or the present day. The source of the increased rainfall is the North African summer monsoon, which brought the highest monthly rainfall to Arabia in the month of August. The 
models suggest that rainfall from Mediterranean winter westerlies was not a major source of increased precipitation.

Figure 5: Winter (January) and summer (August) rainfall levels of the HadCM3 climate model. The summer timeslices for $130 \mathrm{ka}$ and $125 \mathrm{ka}$ show that the North African summer monsoon was the source of increased rainfall into the Peninsula. The spatial distribution of rainfall was not as extensive as that seen in the other models but nevertheless supports the idea that rainfall levels were higher $130 \mathrm{ka}$ and 125 ka than today.

Figure 6: Winter (January) and summer (August) rainfall levels of the HadCM3 climate model. The $104 \mathrm{ka}$ and $56 \mathrm{ka}$ timeslices were investigated because they coincide with known pluvial phases and we wanted to know whether these would be detected in the HadCM3 models. The results are clear in that there was increased rainfall at these times, meaning that multiple climate windows were available for human population movements into the Arabian Peninsula. In contrast, rainfall at 21 ka (Last Glacial Maximum) is low. Figure 7: Winter (January) and summer (August) rainfall levels of the Kiel climate model for 130, 126 and $115 \mathrm{ka}$. The Kiel timeslices show clear evidence for increased rainfall in the Arabian Peninsula from the North African summer monsoon at $130 \mathrm{ka}$ and $126 \mathrm{ka}$, with levels declining by $115 \mathrm{ka}$.

Figure 8: Winter (January) and summer (August) rainfall levels of the NorESM climate model for 130, 125 and $115 \mathrm{ka}$. While the North African summer monsoon is the major source of increased rainfall into Arabia for the three periods, Mediterranean winter rainfall is higher in the north of the Peninsula than the other climate models investigated.

Figure 9: Palaeoenvironmental sites support the CCSM3 climate model scenario for $130 \mathrm{ka}$ particularly well. Speleothem sites are located in areas shaded green on the map where rainfall is $300-600 \mathrm{~mm}$ per year, levels high enough to sustain speleothem growth. All lakes with the exception of Muduwwarra, which has its catchment in the southern Jordan highlands, receive at least $200 \mathrm{~mm}$ of rainfall, as does the fluvial site of $\mathrm{Al}$ Ain.

Figure 10: When Arabian Middle Palaeolithic archaeological sites are plotted on the CCSM3 climate model of $130 \mathrm{ka}$ as an example of a pluvial phase, the majority of sites are in areas of dry to sub-humid rainfall. 


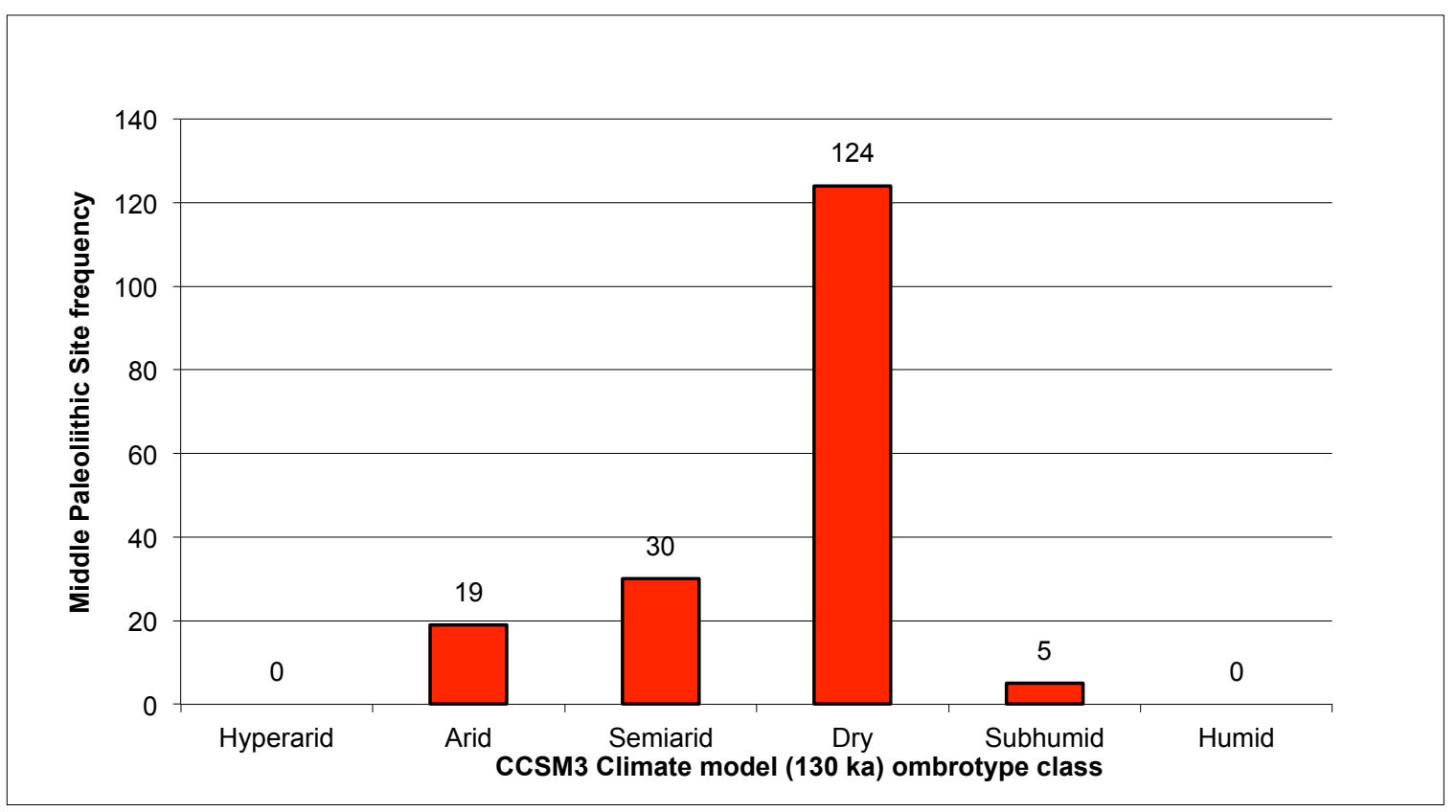

Figure 11: This graph shows that 159 of 178 Middle Palaeolithic sites (89\%) depicted on the CCSM3 climate map for $130 \mathrm{ka}$ (Figure 10) fall within areas that received $>200 \mathrm{~mm}$ of rainfall. The majority of sites were in the dry ombrotype class (300-600 mm per year of rainfall). While Arabia today is largely arid, the distribution of Middle Palaeolithic sites in Arabia can thus be better understood if taking into account that Arabia was wetter in the past, an observation supported by all of the climate models examined in this study.

\section{Tables}

Table 1. Parameters of the five climate models used in this study.

\section{Supplementary Information 1}

All monthly climate model simulations for the COSMOS, HadCM3, KCM and NorESM timeslices used in this paper are available here.

\section{References}

Abo-Monasar, A., Al-Zahrani, M.A., 2014. Estimation of rainfall distribution for the southwestern region of Saudi Arabia, Hydrological Sciences Journal 59, 420-431.

Almazroui, M., 2011. Calibration of TRMM rainfall climatology over Saudi Arabia during 1998-2009. Atmospheric Research 99: 400-414. 
Almazroui, M., Islam, N.M., Athar, H., Jones, P.D., Rahman, M.A., 2012. Recent climate change in the Arabian Peninsula: annual rainfall and temperature analysis of Saudi Arabia for 1978-2009. International Journal of Climatology 32: 953-966.

Al-Subyani, A.M., 2004. Geostatistical study of annual and seasonal mean rainfall patterns in southwest Saudi Arabia. Hydrological Sciences Journal 49, 803-817.

Al-Subyani, A.M., 2005. Hydrochemical identification and salinity problem of ground-water in Wadi Yalamlam basin, Western Saudi Arabia. Journal of Arid Environments 60, 53-66.

Armitage, S.J, Jasim, S.A., Marks, A.E., Parker, A.G., Usik, V.I., Uerpmann, H.-P., 2011. The Southern Route "Out of Africa": Evidence for an Early Expansion of Modern Humans into Arabia. Science 331, 453-456.

Assmann, K. M., Bentsen, M., Segschneider, J., Heinze, C., 2010. An isopycnic ocean carbon cycle model, Geosciencific Model Development 3, 143-167.

Atkinson, O.A.C., Thomas, D.S.G., Parker, A.G., Goudie, A.S., 2013. Late Quaternary humidity and aridity dynamics in the northeast Rub' al-Khali, United Arab Emirates: Implications for early human dispersal and occupation of eastern Arabia. Quaternary International 300, 292-301.

Barth, H.J., Steinkohl, F., 2004. Origin of winter precipitation in the central coastal lowland of Saudi Arabia. Journal of Arid Environments 5, 101-115.

Basell, L.S., 2008. Middle Stone Age (MSA) site distributions in eastern Africa and their relationship to Quaternary environmental change, refugia and the evolution of Homo sapiens Quaternary Science Reviews 27. 2484-2498.

Bentsen, M., Bethke, I., Debernard, J. B., Iversen, T., Kirkevåg, A., Seland, Ø., Drange, H., Roelandt, C., Seierstad, I. A., Hoose, C., Kristjánsson, J. E., 2013. The Norwegian Earth System Model, NorESM1-M - Part 1: Description and basic evaluation of the physical climate, Geoscientific Model Development 6, 687-720. 
Berger, A., 1978. Long-term variations of daily insolation and Quaternary climatic changes. Journal of Atmospheric Sciences 35, 2362-2367.

Berger, A., Loutre, M.F., 1991. Insolation values for the climate of the last 10 million years. Quaternary Science Reviews 10, 297-317.

Boivin, N., Fuller, D.Q., Dennell, R., Allaby, R., Petraglia, M.D., 2013. Human dispersal across diverse environments of Asia during the Upper Pleistocene. Quaternary International 300, $32-47$.

Bosmans, J. H. C., Drijfhout, S. S., Tuenter, E., Hilgen, F. J., Lourens, L. J., 2014. Response of the North African summer monsoon to precession and obliquity forcings in the EC-Earth GCM. Climate Dynamics. DOI 10.1007/s00382-014-2260-z

Braconnot, P., Otto-Bliesner, B., Harrison, S., Joussaume, S., Peterchmitt, J.-Y., Abe- Ouchi, A., Crucifix, M., Driesschaert, E., Fichefet, T., Hewitt, C.D., Kageyama, M., Kitoh, A., La^1ne', A., Loutre, M.-F., Marti, O., Merkel, U., Ramstein, G., Valdes, P., Weber, S.L., Yu, Y., Zhao, Y., 2007. Results of PMIP2 coupled simulations of the Mid-Holocene and Last Glacial Maximum Part 2: feedbacks with emphasis on the location of the ITCZ and mid- and high latitudes heat budget. Climate of the Past 3, 279-296.

Braconnot, P., Marzin, C., Gregoire, L., Mosquet, E., Marti, O., 2008. Monsoon response to changes in Earth's orbital parameters: comparisons between simulations of the Eemian and of the Holocene, Climate Past 4, 281-294.

Braconnot, P., Harrison, S.P., Kageyama, M., Bartlein, P.J., Masson-Delmotte, V., Abe-Ouchi, A., Otto-Bliesner, B. and Zhao, Y. 2012. Evaluation of climate models using palaeoclimatic data. Nature Climate Change 2: 417-424.

Breeze, P.S., Drake, N.A., Groucutt, H.S., Parton, A., Jennings, R.P., Clark-Balzan, L., Shipton, C., White, T.S., Scerri, E., Stimpson, C., Crassard, R., Hilbert, Y., Alsharekh, A., al-Omari, A. and Petraglia, M.D., this issue. Remote sensing and GIS techniques for reconstructing Arabian palaeohydrology and identifying and characterising archaeological sites. Quaternary International 
Bretzke, K., Armitage, S.J., Parker, A.G., Walkington, H., Uerpmann, H.-P., 2013. The environmental context of Paleolithic settlement at Jebel Faya, Emirate Sharjah, UAE. Quaternary International 300, 83-93.

Brayshaw, D.J., Hoskins, B., Black, E. 2010. Some physical drivers of changes in the winter storm tracks over the North Atlantic and Mediterranean during the Holocene. Philosophical Transactions of the Royal Society A 368, 5185-5223.

Brovkin, V., Raddatz, T., Reick, C. H., Claussen, M., Gayler, V., 2003. Global biogeophysical interactions between forest and climate. Geophysical. Research Letters 36, 1-5 .

Cattle, H., Crossley, J., 1995. Modelling Arctic climate-change. Philosophical Transactions of the Royal Society. A 352, 201-213.

Crassard, R., 2009. The Middle Paleolithic of Arabia: The view from the Hadramawt Region, Yemen. In: Petraglia, M., Rose, J. (Eds.), The Evolution of Human Populations in Arabia. Springer, Dordrecht, pp. 151-168.

Crassard, R., Hilbert, Y. H. 2013. A Nubian Complex site from central Saudi Arabia: Implications for taxonomy and human dispersals during the Upper Pleistocene. PLoS ONE 8: e69221.

Crassard, R., Petraglia, M.D., Drake, N.A., Breeze, P., Gratuze, B., Alsharekh, A., Arbach, M., Groucutt, H.S., Khalidi, L., Michelsen, N., Robin, C.J., Schiettecatte, J., 2013. Middle Palaeolithic and Neolithic occupations around Mundafan palaeolake, Saudi Arabia: Implications for climate change and human dispersals. PLoS ONE 8, e69665.

Davies, W., Van Andel, T.H. and Weninger, B., 2003. The Human Presence in Europe during the Last Glacial Period I: Human Migrations and the Changing Climate. In : Van Andel, T.H. ; Davies, W. (Eds.) Neanderthals and modern humans in the European landscape during the last glaciation: archaeological results of the Stage 3 Project. Cambridge, UK, The McDonald Institute for Archaeological Research, 31-56. 
Delagnes, A., Tribolo, C., Bertran, P., Brenet, M., Crassard, R., Jaubert, J., Khalidi, L., Mercier, N., Nomade, S., Peigné, S., Sitzia, S., Tournepiche, J.-F., Al-Halibi, M., Al-Mosabi, A., Macchiarelli, R., 2012. Inland human settlement in southern Arabia 55,000 years ago. New evidence from the Wadi Surdud Middle Paleolithic site complex, western Yemen. Journal of Human Evolution 63, 452-474.

de Noblet-Ducoudre, N., Claussen, R., Prentice, C., 2000. Mid-Holocene greening of the Sahara: First results of the GAIM 6000 year bp experiment with two asynchronously coupled atmosphere/biome models, Climate Dynamics, 16, 659-689.

DiNezio, P.N. ,Tierney, J.E., 2013. The effect of sea level on glacial Indo-Pacific climate, Nature Geoscience 6, 485-491.

Drake, N.A, Blench, R.M, Armitage, S.J, Bristow, C.S, White, K.H., 2011. Ancient watercourses and biogeography of the Sahara explain the peopling of the desert. Proceedings of the National Academy of Sciences 108, 358-462.

Drake, N. A, Breeze, P., Parker, A. G., 2013. Palaeoclimate in the Saharan and Arabian Deserts during the Middle Palaeolithic and the potential for hominin dispersals. Quaternary International 300, 48-61.

Elagib, N.A., Abdu A.S.A., 1997. Climate variability and aridity in Bahrain. Journal of Arid Environments 36, 405-419.

Elagib, N.A., Abdu A.S.A., 2010. Development of temperatures in the Kingdom of Bahrain from 1947 to 2005. Theoretical and Applied Climatology 101, 269-279.

Eriksson A., Betti, L., Friend A.D., Lycett S.J., Singarayer J.S., Von Cramon N., Valdes P.J., Balloux F., Manica A., 2012. Late Pleistocene climate change and the global expansion of anatomically modern humans. Proceedings of the National Academy of Sciences. 109, 16089-16094.

Essery, R., M. Best, Cox, P., 2001. MOSES 2.2 technical documentation, Hadley Centre Technical Note. 
Finlayson, C. 2014. The Improbable Primate: How Water Shaped Human Evolution. Oxford University Press, Oxford.

Fleitmann, D., Burns, S.J., Neff, U., Mudelsee, M., Mangini, A., Matter, A., 2004.

Palaeoclimatic interpretation of high-resolution oxygen isotope profiles derived from annually laminated speleothems from Southern Oman. Quaternary Science Reviews 23, 935-945.

Fleitmann, D., Burns, S.J., Mangini, A., Mudelsee, M., Kramers, J., Villa, I., Neff, U., Al-Subbary, A.A., Buettner, A., Hippler, D., Matter, A., 2007. Holocene ITCZ and Indian monsoon dynamics recorded in stalagmites from Oman and Yemen (Socotra). Quaternary Science Reviews 26, 170-188.

Freiwana, M., Kadioglu, M., 2008. Climate variability in Jordan. International Journal of Climatology. 28, 69-89.

Frumkin, A., Bar-Yosef, O., Schwarcz, H., 2011. Possible paleohydrologic and paleoclimatic effects on hominin migration and occupation of the Levantine Middle Paleolithic. Journal of Human Evolution 60, 437-451.

Furl, C., Sharif, H.O., Alzahrani, M., El Hassan, A., Mazari N., 2014. Precipitation amount and intensity trends across southwest Saudi Arabia. Journal Of The American Water Resources Association 50, 74-82.

Gent, P.R., McWilliams, J.C., 1990. Isopycnal mixing in ocean circulation models. Journal of Physical. Oceanography 20, 150-155.

Gordon, C., Cooper, C., Senior, C.A., Banks, H., Gregory, J.M., Johns, T.C., Mitchell, J.F.B., Wood, R.A., 2000. The simulation of SST, sea ice extents and ocean heat transports in a version of the Hadley Centre coupled model without flux adjustments. Climate Dynamics 16, 147168.

Groucutt, H.S., Petraglia, M.D., 2012. The Prehistory of the Arabian Peninsula: Deserts, 
Dispersals and Demography. Evolutionary Anthropology 21, 113-125.

Groucutt, H.S, Blinkhorn, J., 2013. The Middle Palaeolithic in the Desert and its implications for understanding hominin adaptation and dispersal. Quaternary International 300, 1-12.

Groucutt, H.S., Petraglia, M.D., 2014. An Arabian perspective on the dispersal of Homo sapiens out of Africa. In: Dennell, R., Porr, M., (Eds.), South Asia, Australia and Human Origins. Cambridge University Press, Cambridge, pp. 51-63.

Groucutt, H.S., Shipton, C., Alsharekh, A., Jennings, R.P., Scerri, E.M.L., Petraglia, M.D. this issue. The lithic assemblage of Jebel Katefeh-1, Jubbah: Upper Pleistocene hominin settlement of the desert interior of Saudi Arabia. Quaternary International

Grün, R., Stringer, C., McDermott, F., Nathan, R., Porat, N., Robertson, S., Taylor, L., Mortimer, G., Eggins, S., McCulloch, M. 2005. U-series and ESR analyses of bones and teeth relating to the human burials from Skhul. Journal of Human Evolution. 49, 316-334.

Heiri O, Brooks S.J., Renssen, H., Bedford, Q.A., Hazekamp, M., Ilyashuk, B., Jeffers, E.S., Lang, B., Kirilova, E., Kuiper, S., Millet, L., Samartin, S., Toth, M., Verbruggen, F., Watson, J.E., van Arsch, N., Lammertsma, E., Amon, L., Birks, H.H., Birks, H.J.B., Mortensen, M.F., Hoek, W.Z., Magyari, E., Sobrino, C.M., Seppä, H., Tinner, W., Tonkov, S., Veski, S., Lotter, A.F., 2014: Validation of climate model-inferred regional temperature change for late-glacial Europe. Nature Communications, Vol. 5, No. 4914.

Henderson-Sellers, A., Robinson, P.J., 1991. Contemporary Climatology. New York, USA: Longman Scientific and Technical.

Hibler, W., III A dynamic thermodynamic sea ice model. Journal of Physical Oceanography. 9, 815-846.

Hijmans, R.J., Cameron, S.E., Parra, J.L., Jones, P.G., Jarvis, A., 2005. Very high resolution interpolated climate surfaces for global land areas. International Journal of Climatology 25, 1965-1978. 
Inizan, M-L. Ortlieb, L. 1987. Prehistoire dans la region de Shabwa au Yemendu sud (R.D.P. Yemen). Paleorient 13, 5-22.

Jagher, R., 2009. The Central Oman Paleolithic Survey: Recent research in southern Arabia and reflection on the prehistoric evidence," In Petraglia, M.D., Rose, J.J., (Eds.), The Evolution of Human Populations in Arabia. Netherlands: Springer, 139-150.

Iversen, T., Bentsen, M., Bethke, I., Debernard, J. B., Kirkevåg, A., Seland, Ø., Drange, H., Kristjansson, J. E., Medhaug, I., Sand, M., Seierstad, I. A., 2013. The Norwegian Earth System Model, NorESM1-M - Part 2: Climate response and scenario projections, Geoscientific Model Development 6, 389-415.

Jeffers, D., Willis, K.J., 2014. Vegetation response to climate change during the Last Interglacial-Last Glacial transition in the southern Bekaa Valley, Lebanon. Palynology, DOI:10.1080/01916122.2014.880958.

Jennings, R.P., Finlayson, J.C., Fa, D.A., Finlayson, G., 2011. Southern Iberia as a refuge for the last Neanderthal populations, Journal of Biogeography 38, 1873-1885.

Jones, P.G., Thornton, P.K., Heinke, J., 2009. Generating characteristic daily weather data using downscaled climate model data from the IPCC's Fourth Assessment. Project Report. Nairobi (Kenya): ILRI.

Kalimeris, A., Founda, D., Giannakopoulos, C., Pierros, F., 2011. Long-term precipitation variability in the Ionian Islands, Greece (Central Mediterranean): climatic signal analysis and future projections. Theoretical and Applied Climatology 109, 51-72.

Khon, V.C., Park, W., Latif, M., Mokhov, I., Schneider, B., 2010. Response of the hydrological cycle to orbital and greenhouse gas forcing. Geophysical Research Letters, 37, L19705.

Krichak S.O., Tsidulko M., Alpert P., 2000. Monthly synoptic patterns associated with wet/dry conditions in the eastern Mediterranean. Theoretical and Applied Climatology 65: 215-229. 
Kwarteng, A. Y., Dorvlo, A.S., Vijaya Kumar, G.T., 2009. Analysis of a 27-year rainfall data (1977-2003) in the Sultanate of Oman. International Journal of Climatology 29, 605-617.

Langebroek, P.M., Nisancioglu, K. H., 2014. Simulating last interglacial climate with NorESM: role of insolation and greenhouse gases in the timing of peak warmth, Climate Past 10, 1305-1318.

Larrasoaña J.C., Roberts A.P., Rohling, E.J., 2013. Dynamics of Green Sahara Periods and Their Role in Hominin Evolution. PLoS ONE 8: e76514.

Lunt, D. J., Abe-Ouchi, A., Bakker, P., Berger, A., Braconnot, P., Charbit, S., Fischer, N., Herold, N., Jungclaus,J. H., Khon, V. C., Krebs-Kanzow, U., Langebroek, P. M., Lohmann, G., Nisancioglu, K. H., Otto-Bliesner,B., Park, W., Pfeiffer, M., Phipps, S. J., Prange, M., Rachmayani, R., Renssen, H., Rosenbloom,N., Schneider, B., Stone, E. J., Takahashi, K., Wei, W., Yin, Q. 2013. A multi-model assessment of last interglacial temperatures. Climate of the Past, 9, 699-717.

Madec, G., 2006. NEMO reference manual, ocean dynamics component: NEMO-OPA. Preliminary version, Note Pole Model. 27, Inst. Pierre-Simon Laplace, Paris.

Marks, A. E. 2009. The Paleolithic of Arabia in an Inter-regional Context. In: Petraglia, M. D. and Rose, J. I. (Eds.), The Evolution of Human Populations in Arabia. Springer, Dortrecht, pp. 295-308.

Marsland, S. J., Haak, H., Jungclaus, J. H., Latif, M. and Röske, F., 2003. The Max-PlanckInstitute global ocean/sea ice model with orthogonal curvilinear coordinates. Ocean Model. $5,91-127$.

McClure, H.A., 1976. Radiocarbon chronology of Late Quaternary lakes in the Arabian Desert. Nature 263, 755-756.

Mellars, P. Gori, K.C., Carr, M., Soares, P.A., Richards, M.B., 2013. Genetic and archaeological perspectives on the initial modern human colonization of southern Asia. Proceedings of the National Academy of Sciences 110, 10699-10704. 
Otto-Bliesner, B., S. Marshall, J. Overpeck, G. Miller, and A. Hu, 2006: Simulating Arctic climate warmth and icefield retreat in the last interglaciation. Science, 311, 1751-1753.

Oppenheimer, S., 2009. The great arc of dispersal of modern humans: Africa to Australia. Quaternary International 202, 2-13.

Park, W., Keenlyside, N., Latif, M., Stroeh, A., Redler, R., Roeckner, E., Madec, G., 2009. Tropical Pacific climate and its response to global warming in the Kiel Climate Model, Journal of Climatology 22, 71-92.

Parker, A.G., Goudie, A.S., Stokes, S., White, K., Hodson, M.J., Manning, M., Kennet, D., 2006. A record of Holocene climate change from lake geochemical analyses in southeastern Arabia. Quaternary Research 66, 465-476.

Parker, A.G., 2009. Pleistocene Climate Change in Arabia: Developing a Framework for Hominin Dispersal over the Last 350ka. In: Petraglia M., Rose, J. (Eds.), The Evolution of Human Populations in Arabia. Springer, Dortrecht, pp. 39-50.

Parton, A., Farrant, A.R., Leng, M.J., Schwenninger, J.L., Rose, J.I., Uerpmann, H.P., Parker, A.G. An early MIS 3 pluvial phase in Southeast Arabia: Climatic and archaeological implications, Quaternary International, 300, 62-74.

Parton, A., Farrant, A.R., Leng, M.J., Telfer, M., Groucutt, H.S., Petraglia, M.D., Parker, A.G., 2014. Alluvial fan records from southeast Arabia reveal multiple windows for human dispersal. Geology, in submission.

Parton, A., White, T.S., Parker, A.G., Breeze, P.S., Groucutt, H.S. Jennings, R.P. \& Petraglia, M.D., this issue. Orbital-scale monsoon variability and the greening of Arabia as a motor for human dispersal. Quaternary International

Petit-Maire, N., Carbonel, P., Reyss, J.L., Sanlaville, P., Abed, A., Bourrouilh, R., Fontugne, M., Yasin, S., 2010. A vast Eemian palaeolake in Southern Jordan (29_N). Global and Planetary Change 72, 368-373. 
Petraglia, M. D. and Alsharekh, A. 2003. The Middle Palaeolithic of Arabia: implications for modern human origins, behaviour and dispersals. Antiquity 77, 671-684.

Petraglia, M.D., 2011. Trailblazers across Arabia. Nature 470, 50-51.

Petraglia, M.D., Alsharekh, A., Breeze, P., Clarkson, C., Crassard, R., Drake, N.A., Groucutt, H.S., Jennings, R.P., Parker, A.G., Parton, A., Roberts, R.G., Shipton, C., Matheson, C., al-Omari, A., Veall, M.-A., 2012. Hominin Dispersal into the Nefud Desert and Middle Palaeolithic Settlement along the Jubbah Palaeolake, Northern Arabia. PLoS ONE 7, e49840.

Pfeiffer, M., Lohmann, G., 2013. The Last Interglacial as Simulated by an Atmosphere-Ocean General Circulation Model: Sensitivity Studies on the Influence of the Greenland Ice Sheet. in Lohmann, G.; Grosfeld, K.; Wolf-Gladrow, D.; Unnithan, V.; Notholt, J.; Wegner, A. (Eds.) Earth System Science: Bridging the Gaps between Disciplines Perspectives from a Multidisciplinary Helmholtz Research School, Springer Briefs in Earth System Sciences, 57-64.

Pope, V.D., Gallani, M.L., Rowntree, P.R., Stratton, R.A., 2000. The impact of new physical parameterisations in the Hadley Centre climate model: HadAM3. Climate Dynamics 16, 123-146.

Rehman S., 2010. Temperature and rainfall variation over Dhahran, Saudi Arabia, (19702006). International Journal of Climatology 30, 445-449.

Roeckner, E., Baeuml, G., Bonaventura, L., Brokopf, R., Esch, M., Giorgetta, M., Hagemann, S., Kirchner, I., Kornblueh, L., Manzini, E., Rhodin, A., Schlese, U., Schulzweida, U., Tompkins, A., 2003. The atmospheric general circulation model ECHAM5. Part I: Model description, Max Planck Institute for Meteorology Report 349.

Rose, J.I., Usik, V.I., Marks, A.E., Hilbert, Y.H., Geiling, J.M., Galletti, C.S., Parton, A., Morley, M.W., Cerny, V., Roberts, R.G. 2011. The Nubian Complex of Dhofar, Oman and implications for early modern human occupation of southern Arabia. PLoS One 6, e28239. 
Rosenberg, T.M., Preusser, F., Fleitmann, D., Schwalb, A., Penkman, K., Schmid, T.W., AlShanti, M.A., Kadi, K., Matter, A., 2011. Late Pleistocene pluvial periods in southern Arabia windows of opportunity for modern human dispersal. Geology 39, 1115-1118.

Rosenberg, T.M., Preusser, F., Risberg, J., Plikk, A., Kadi, K.K., Matter, A., Fleitmann, D., 2013. Middle and Late Pleistocene humid periods recorded in palaeolake deposits of the Nafud desert, Saudi Arabia. Quaternary Science Reviews 70, 109-123.

Scerri, E.M.L., Breeze, P., Parton, A., Groucutt, H.S., Stimpson, C., Clark-Balzan, L. Jennings, R.P., White, T., Petraglia, M.D. This issue, Landscape archives and Middle to Late Pleistocene human habitation in the Nefud Desert, Saudi Arabia. Quaternary International.

Scerri, E.M.L., Groucutt, H.S., Jennings, R.P., Petraglia, M.D., 2014. Unexpected technological heterogeneity in Arabia indicates geographically diverse tool traditions and a complex outof-Africa dispersal history. Journal of Human Evolution. DOI: 10.1016/j.jhevol.2014.07.002

Singarayer J.S., and Valdes, P.J., 2010. High-latitude climate sensitivity to ice-sheet forcing over the last 120 ka. Quaternary. Science. Reviews 29, 43-55.

Trigo, R.M., Gouveia, C.M., Barriopedro, D., 2010. The intense 2007-2009 drought in the Fertile Crescent: Impacts and associated atmospheric circulation. Agricultural and Forest Meteorology 150, 1245-1257.

Usik, V. I., Rose, J. I., Hilbert, Y. H., Van Peer, P., Marks, A. E. 2013. Nubian Complex reduction strategies in Dhofar, southern Oman. Quaternary International 300, 244-266.

van Rampelbergh M., Fleitmann D., Verheyden S., Cheng H., Edwards L., De Geest P. and De Vleeschouwer D., 2013. Mid to late Holocene Indian Ocean Monsoon variability recorded in four speleothems from Socotra Island, Yemen. Quaternary Science Reviews 65, 129-142.

Vaks, A., Bar-Matthews, M., Matthews, A., Ayalon, A., Frumkin, A., 2010. Middle-Late Quaternary paleoclimate of northern margins of the Saharan-Arabian Desert: reconstruction from the speleothems of Negev Desert, Israel. Quaternary Science Reviews 29, 2647-2662. 
Zhang, Z. S., Nisancioglu, K., Bentsen, M., Tjiputra, J., Bethke, I., Yan, Q., Risebrobakken, B., Andersson, C., Jansen, E., 2012. Pre-industrial and mid-Pliocene simulations with NorESML, Geoscientific. Model Development 5, 523-533.

Zhang, X., Lohmann, G., Knorr, G., Xu, X., 2013. Different ocean states and transient characteristics in Last Glacial Maximum simulations and implications for deglaciation, Climate Past 9, 2319-2333. 